\title{
Catalytic diesel particulate filters reduce the in vitro estrogenic activity of diesel exhaust
}

\author{
Journal Article \\ Author(s): \\ Wenger, Daniela; Gerecke, Andreas C.; Heeb, Norbert V.; Naegeli, Hanspeter; Zenobi, Renato \\ Publication date: \\ 2008 \\ Permanent link: \\ https://doi.org/10.3929/ethz-b-000004819 \\ Rights / license: \\ In Copyright - Non-Commercial Use Permitted \\ Originally published in: \\ Analytical and Bioanalytical Chemistry 390(8), https://doi.org/10.1007/s00216-008-1872-8
}




\title{
Catalytic diesel particulate filters reduce the in vitro estrogenic activity of diesel exhaust
}

\author{
Daniela Wenger • Andreas C. Gerecke • \\ Norbert V. Heeb • Hanspeter Naegeli • Renato Zenobi
}

Received: 26 September 2007 /Revised: 14 December 2007 / Accepted: 10 January 2008 /Published online: 9 February 2008

(C) Springer-Verlag 2008

\begin{abstract}
An in vitro reporter gene assay based on human breast cancer T47D cells (ER-CALUX ${ }^{\circledR}$ ) was applied to examine the ability of diesel exhaust to induce or inhibit estrogen receptor (ER)-mediated gene expression. Exhaust from a heavy-duty diesel engine was either treated by ironor copper/iron-catalyzed diesel particulate filters (DPFs) or studied as unfiltered exhaust. Collected samples included particle-bound and semivolatile constituents of diesel exhaust. Our findings show that all of the samples contained compounds that were able to induce ER-mediated gene expression as well as compounds that suppressed the activity of the endogenous hormone $17 \beta$-estradiol (E2). Estrogenic activity prevailed over antiestrogenic activity. We found an overall ER-mediated activity of $1.63 \pm 0.31 \mathrm{ng}$ E2 CALUX equivalents (E2-CEQs) per $\mathrm{m}^{3}$ of unfiltered exhaust. In
\end{abstract}

Electronic supplementary material The online version of this article (doi:10.1007/s00216-008-1872-8) contains supplementary material, which is available to authorized users.

D. Wenger · A. C. Gerecke $(\bowtie) \cdot$ N. V. Heeb

Laboratory for Analytical Chemistry, Empa,

Swiss Federal Laboratories for Materials Testing and Research, 8600 Dübendorf, Switzerland

e-mail: andreas.gerecke@empa.ch

H. Naegeli

Institute of Pharmacology and Toxicology,

University of Zurich-Vetsuisse,

8057 Zurich, Switzerland

R. Zenobi

Department of Chemistry and Applied Biosciences, ETH Zurich,

8093 Zurich, Switzerland filtered exhaust, we measured $0.74 \pm 0.07$ (iron-catalyzed DPF) and $0.55 \pm 0.09 \mathrm{ng}$ E2-CEQ m ${ }^{-3}$ (copper/iron-catalyzed DPF), corresponding to reductions in estrogenic activity of 55 and $66 \%$, respectively. Our study demonstrates that both catalytic DPFs lowered the ER-mediated endocrine-disrupting potential of diesel exhaust.

Keywords Diesel exhaust - Diesel particles .

Diesel particulate filter In vitro reporter gene assay .

Estrogen receptor Estrogenic activity

\begin{tabular}{|c|c|}
\hline \multicolumn{2}{|c|}{ Abbreviations } \\
\hline AhR & Aryl hydrocarbon receptor \\
\hline ANOVA & One-way analysis of variance \\
\hline $\mathrm{Cl}$ & Chlorine-enriched diesel fuel $\left(14 \mu \mathrm{g} \mathrm{g}^{-1}\right)$ \\
\hline $\mathrm{Cu}$ & $\begin{array}{l}\text { Diesel fuel with copper/iron-based fuel } \\
\text { additive }\left(9.0 / 7.5 \mu \mathrm{g} \mathrm{g}^{-1}\right)\end{array}$ \\
\hline DMSO & Dimethylsulfoxide \\
\hline DPF & Diesel particulate filter \\
\hline E2 & $17 \beta$-Estradiol \\
\hline EE2 & $17 \alpha$-Ethinylestradiol \\
\hline E2-CEQ & $17 \beta$-Estradiol CALUX equivalent \\
\hline ER & Estrogen receptor; \\
\hline ER- & Estrogen Responsive-Chemically Activated \\
\hline CALUX $^{\circledR}$ & LUciferase eXpression \\
\hline $\mathrm{F}$ & Exhaust treatment by diesel particulate filter \\
\hline FBS & Fetal bovine serum \\
\hline $\mathrm{Fe}$ & $\begin{array}{l}\text { Diesel fuel with iron-based additive } \\
\left(4.5 \mu \mathrm{g} \mathrm{g}^{-1}\right)\end{array}$ \\
\hline $\mathrm{PCDD} / \mathrm{Fs}$ & Polychlorinated dibenzodioxins/furans \\
\hline Ref & Reference diesel fuel \\
\hline RSD & Relative standard deviation \\
\hline $\mathrm{xCl}$ & Chlorine-enriched diesel fuel $\left(110 \mu \mathrm{g} \mathrm{g}^{-1}\right)$ \\
\hline
\end{tabular}




\section{Introduction}

Diesel engines emit a complex mixture of carbonaceous soot particles and hundreds of particle-bound or gaseous compounds [1]. Diesel combustion contributes appreciable numbers of fine $(<2.5 \mu \mathrm{m}$ aerodynamic diameter) and ultrafine $(<0.1 \mu \mathrm{m})$ particles to the air in urban and heavy traffic areas [2] and in work places such as mines and construction sites [3]. Exposure to diesel exhaust and particularly to diesel exhaust particles is associated with airway inflammation, asthma, allergies, cardiovascular diseases [4, 5], and probably also with lung cancer [6]. Compounds emitted by diesel engines exhibit various chemical structures, physicochemical properties, toxicities, and physiological effects. Some of these compounds are potential or known endocrine disruptors $[7,8,9]$. By mimicking or antagonizing naturally occurring hormones and/or by modulating hormonal responses, endocrine disruptors interfere with the normal functioning of endocrine systems in humans and animals and thereby lead to adverse health effects (reviewed in $[10,11])$. Chemicals capable of disrupting the action of sex hormones (e.g., of estrogens) have received most attention. This is due to their endocrine-disrupting effects, as observed in laboratory animals; their potential role in wildlife reproductive problems; and their potential association with reproductive disorders and hormone-sensitive cancers in humans $[10,11]$.

In our study, we investigated the estrogenic and antiestrogenic activity of diesel exhaust. We used an in vitro reporter gene assay, the Estrogen Responsive-Chemically Activated LUciferase gene eXpression (ER-CALUX ${ }^{\circledR}$ ) assay [12], to detect and measure compounds that induce or inhibit gene expression mediated by the estrogen receptor (ER). Alterations in gene expression are thought to represent an early but critical step in the regulation of biological processes [11]. The ER, of which two subtypes have been found in humans (i.e., $\mathrm{ER} \alpha, \mathrm{ER} \beta$ ), belongs to the nuclear receptor superfamily (reviewed in [13]). It functions as a ligandinducible transcription factor, mediating the effects of natural estrogens, of which $17 \beta$-estradiol (E2) is the major endogenous estrogen. Estrogens regulate the growth, differentiation, and functioning of diverse target tissues. Compounds that bind competitively to the ER are defined as direct-acting estrogenic and antiestrogenic compounds [14]. These ER ligands act either as agonists or antagonists at the receptor. Upon binding, ER agonists induce conformational changes in the receptor, which lead via a number of events to receptor dimerization, receptor-DNA interaction, and finally to changes in the transcription rate of estrogen-responsive genes [13]. In the case of CALUX cells, the ER-controlled reporter gene coding for luciferase is also expressed [12]. In contrast to ER agonists, antagonists block the action of estrogens. Direct-acting ER antagonists such as ICI 182,780, a $7 \alpha$-alkylsulphinyl analog of E2, bind to the ER competitively and inhibit the transcription of ER-regulated genes [15]. However, certain compounds do not evoke direct effects on the estrogen system via binding to the ER. Aryl hydrocarbon receptor (AhR) agonists, such as polychlorinated dibenzodioxins and furans $(\mathrm{PCDD} / \mathrm{Fs})$, induce antagonistic effects on the ER signal transduction pathway, probably via several other mechanisms (reviewed in [16]). In summary, compounds present in diesel exhaust may exhibit complex interactions with the ER and its signal transduction pathways. Estrogen-sensitive reporter gene assays, such as the ERCALUX $^{\circledR}$ assay, integrate the ER-mediated activity exhibited by all estrogenic or antiestrogenic compounds, either known or unidentified, present in a sample [12].

Preceding in vitro studies have shown that diesel particles, a fraction of the diesel exhaust, contain potential endocrine disruptors that may modulate the activity of estrogens in vivo. For example, Meek [17] reported that compounds present in extracts of diesel particles activated the ER in MCF-7 human breast cancer cells and the AhR in Hepa1c1c7 mouse hepatoma cells. Okamura et al. [18] observed antiestrogenic activity in MCF-7 cells induced by extracts of diesel particles. No significant estrogenic activity was found when testing a single concentration of each extract; however, a study on the dose-dependent response was not reported. Wang et al. [19] found weak but clear estrogenic activity in an extract of diesel particles, using a human ER recombinant yeast assay. Furuta et al. [8] isolated nitrophenols from diesel particles and showed that 3methyl-4-nitrophenol and 4-nitro-3-phenylphenol exhibited estrogenic activity in a recombinant yeast assay, in a myometrial contractility assay, and in an in vivo uterotrophic assay. Other in vivo findings have demonstrated that exposure to diesel exhaust affects both the male and female reproductive systems of rats [20-22] and mice [22-24]. Epidemiologic studies have suggested that occupational exposure to diesel exhaust elevates the risk of ovarian cancer in female workers from different fields [25] and decreases semen quality in motorway tollgate workers [26].

In contrast to previous in vitro investigations, the study presented herein examines the ER-mediated activity of integral samples, including particle-bound and semivolatile constituents of diesel exhaust. Exhaust was collected from a heavy-duty diesel engine operated according to an eightstage test cycle (ISO 8178/4 C1), which covers typical field conditions. The overall ER-mediated activity was quantified as equivalents of E2. We also investigated the influence of dose and exposure time on ER-mediated activity of diesel exhaust. Furthermore, we evaluated effects of catalytic diesel particulate filters (DPFs) on emissions of estrogenic and antiestrogenic compounds.

DPFs were developed to counteract adverse health effects associated with diesel particles. Most current DPF 
technologies lower the number of emitted particles by more than $95 \%$ [3, 27]. Besides this primary effect, secondary effects also occur, which result from physical filtering of particle-associated compounds and from chemical transformation of exhaust constituents (i.e., formation and degradation) within DPFs. Unwanted side-reactions, such as halogenation or nitration of primary exhaust constituents, may lead to increased emissions of toxic compounds. Conditions in the DPF that promote such unfavorable secondary effects are described elsewhere [3, 7]. In summary, primary and secondary effects of DPFs alter the composition of diesel exhaust. Thus, the application of DPFs may also affect emissions of estrogenic and antiestrogenic compounds. As a consequence, ER-mediated activity of the exhaust will increase or decrease. For example, under the assumption that the influence of antiestrogenic compounds is negligible, a decrease in ER-mediated activity is expected if an appreciable amount of ER agonists is sorbed (i.e., adsorbed or absorbed [28]) to trapped diesel particles and no secondary formation of ER agonists occurs.

Three major classes of DPFs can be distinguished depending on the strategy used for the filtering and combustion of diesel particles: (i) filters built of porous or fibrous substrates coated with catalysts, typically noble metals, (ii) filters consisting of uncoated substrates, which accumulate fuelborne catalysts, typically transition metal oxides, and (iii) uncoated filters, which use active regeneration, for example burners [1]. DPF regeneration demands a minimum temperature of $550{ }^{\circ} \mathrm{C}$ and an oxygen content of $5 \%$, which cannot be attained without catalytic combustion or additional burners/ heaters [1, 29]. In the present study, we evaluated two commercial, uncoated, cordierite-based, wall-flow DPFs, for which soot combustion was catalyzed with either an iron- or a copper/iron-based fuel additive. We investigated effects of both DPF systems on the ER-mediated activity of the exhaust, using either chlorine-free or chlorine-enriched diesel fuels. As discussed elsewhere [3, 7], experimental conditions with chlorine-enriched fuel represent a worst case scenario with respect to the secondary formation of chlorinated AhR agonists, such as PCDD/Fs.

\section{Experimental}

Diesel engine operation, sampling devices, and exhaust sampling

Exhaust was generated using a heavy-duty diesel engine with direct fuel injection (type D914T, 6.11 L, 4 cylinders, $105 \mathrm{~kW}$, Liebherr, Bulle, Switzerland). The engine was run with commercial low-sulfur diesel fuel (class D, SN 1811901:2000, density: $824.3 \mathrm{~kg} \mathrm{~m}^{-3}$, cetane number: 56.0 , sulfur: $16 \mathrm{mg} \mathrm{kg}^{-1}$ ), subsequently called reference fuel, and oper- ated according to the eight-stage ISO $8178 / 4 \mathrm{C} 1$ test cycle valid for construction site engines ("Electronic supplementary material," Fig. S1). Emission factors for regulated pollutants and $\mathrm{CO}_{2}$ are discussed elsewhere [3]. Sampling was performed according to the filter/condenser method described in European Standard EN-1948-1 [30]. All-glass sampling devices ("Electronic supplementary material," Fig. S2), consisting of a sampling probe, a quartz fiber filter, a cooler, a condensate separator, and a two-stage adsorber unit (XAD-2), were used to obtain samples that included particle-bound and semivolatile compounds. Samples were collected in individual sampling devices, which had all been cleaned and heated up to $450{ }^{\circ} \mathrm{C}$ to remove any traces of organic contaminants. Mass flow proportional aliquots of undiluted exhaust were taken during two consecutive runs (200 $\mathrm{min}$ ) of the test cycle, yielding $4-7 \mathrm{~m}^{3}$ of exhaust per sample. Table 1 describes the collected samples.

Diesel particulate filters and fuel additives

Two new, uncoated, cordierite-based, monolithic, wall-flow DPFs (100 CPSI, 22.8 L, Greentop, Grävenwiesbach, Germany) were tested in combination with an iron- or a copper/iron-based fuel additive as catalysts (ITN, Krakow, Poland). Both additives were mixed with reference fuel to yield two blends with final iron and copper/iron concentrations of 4.5 and 9.0/7.5 $\mathrm{gg} \mathrm{g}^{-1}$, respectively, as determined by inductively coupled plasma optical emission spectrometry (ICP-OES, Vista Pro, Varian, Palo Alto, CA, USA) [3]. The chemical compositions of these fuel additives have not been released into the public domain.

Chlorine, in the form of 1,6-dichlorohexane (Fluka, Buchs, Switzerland), was mixed with reference fuel, resulting in chlorine levels of 14 and $110 \mu \mathrm{g} \mathrm{Cl} \mathrm{g}^{-1}$, as determined by wavelength dispersed X-ray fluorescence spectrometry

Table 1 Experimental conditions during the generation of diesel exhaust samples

\begin{tabular}{llll}
\hline Sample code $^{\mathrm{a}}$ & Chlorine $\left[\mu \mathrm{g} \mathrm{g}^{-1}\right]$ & Fuel additive $\left[\mu \mathrm{g} \mathrm{g}^{-1}\right]$ & $\mathrm{DPF}^{\mathrm{b}}$ \\
\hline $\mathrm{Ref}$ & none $(<2)$ & none $(<0.1 /<0.1)$ & none \\
$\mathrm{Fe}$ & none $(<2)$ & $\mathbf{F e}(4.5)$ & none \\
$\mathrm{FeF}$ & none $(<2)$ & $\mathbf{F e}(4.5)$ & $\mathbf{F}$ \\
$\mathrm{Cu}$ & none $(<2)$ & $\mathbf{C u}(9) / \mathrm{Fe}(7.5)$ & none \\
$\mathrm{CuF}$ & none $(<2)$ & $\mathbf{C u}(9) / \mathrm{Fe}(7.5)$ & $\mathbf{F}$ \\
$\mathrm{Cl}$ & $\mathbf{C l}(14)$ & none $(<0.1 /<0.1)$ & none \\
$\mathrm{ClFe}$ & $\mathbf{C l}(14)$ & $\mathbf{F e}(4.5)$ & none \\
$\mathrm{ClFeF}$ & $\mathbf{C l}(14)$ & $\mathbf{F e}(4.5)$ & $\mathbf{F}$ \\
$\mathrm{ClCuF}$ & $\mathbf{C l}(14)$ & $\mathbf{C u}(9) / \mathrm{Fe}(7.5)$ & $\mathbf{F}$ \\
$\mathrm{xClCuF}$ & $\mathbf{x C l}(110)$ & $\mathbf{C u}(9) / \mathrm{Fe}(7.5)$ & $\mathbf{F}$ \\
\hline
\end{tabular}

${ }^{\text {a }}$ A low-sulfur diesel fuel was used in all experiments: Ref, reference fuel; $\mathbf{F e}$, reference fuel with iron-based additive; $\mathbf{C u}$, reference fuel with copper/iron-based additive; $\mathbf{C l}, \mathbf{x C l}$, chlorine-enriched reference fuel; F, exhaust treatment by diesel particulate filter (DPF). ${ }^{\mathrm{b}}$ Two new, uncoated, cordierite-based, wall-flow DPFs (Greentop) were tested 
(WD-XRF, PW 2400, Philips, Eindhoven, the Netherlands) [3]. This simulated a worst case scenario for the secondary formation of chlorinated AhR agonists such as PCDD/Fs [3, 7]. Hence, the effects of both DPFs on the ER-mediated activity of the exhaust were studied using chlorine-free $\left(<2 \mu \mathrm{g} \mathrm{Cl} \mathrm{g}^{-1}\right.$ [3]) and chlorine-enriched fuels (Table 1).

\section{Sample extraction}

Solvents were pro-analysis quality or better, and were purchased from Merck (Darmstadt, Germany) or Biosolve (Valkenswaard, The Netherlands). The details of the sample extraction are given elsewhere [7]. Each sampling device was rinsed with solvents (acetone, toluene, dichloromethane), which were subsequently pooled with the extracted condensate. The pooled extract was concentrated, transferred to toluene, and used to extract adsorbents and filter materials in a Soxhlet apparatus for $24 \mathrm{~h}$. The Soxhlet extract was concentrated to a final volume of approximately $1 \mathrm{ml}$. Five percent (w/w) was transferred to a volumetric flask and adjusted to $20 \mathrm{ml}$. From this, $0.25-0.75 \mathrm{ml}$ were used to prepare samples for ERCALUX ${ }^{\circledR}$ analysis. The solvent was evaporated $\left(50^{\circ} \mathrm{C}, \mathrm{N}_{2}\right)$ and, at the point of dryness, $0.01 \mathrm{ml}$ of dimethylsulfoxide (DMSO, extra pure, Merck, Darmstadt, Germany) was added. Samples in DMSO were stored in the dark at $4{ }^{\circ} \mathrm{C}$.

\section{Blank control and sampling spike}

A sampling device that was not used for sampling was extracted and prepared for assay analysis as described above. This yielded a blank control covering sampling, extraction, and sample preparation for assay analysis. The average sample volume $\left(5.8 \mathrm{~m}^{3}\right)$ was used to calculate the assay response of the blank control per $\mathrm{m}^{3}$ of diesel exhaust. We determined an E2-CEQ concentration of $0.12 \pm 0.04 \mathrm{ng}$ E2CEQ $\mathrm{m}^{-3}$ in the blank control. This was 5-16 times below the concentrations detected in the exhaust samples.

As described elsewhere [7], a ${ }^{13} \mathrm{C}$-labeled mixture of compounds (naphthalene, phenanthrene, pyrene, and 1,2,3,4,6,7-hexachlorodibenzodioxin) was spiked to the sampling devices to estimate overall sampling and workup recoveries. The final DMSO solution of the sampling spike did not exhibit any detectable ER-mediated activity.

\section{Reporter gene assay}

The ER-CALUX ${ }^{\circledR}$ assay is an in vitro reporter gene assay used to detect ER-mediated gene expression [12]. The assay is based on human breast adenocarcinoma T47D cells that are stably transfected with the ER-controlled luciferase reporter gene construct pEREtata-Luc (i.e., T47D.Luc cells). ER agonists induce luciferase gene expression in a dose-dependent manner and are indirectly detected via luciferase activity.
Cell culture and assay analyses were performed as previously described [31]. All media and supplements used were from Gibco (Paisley, Scotland). T47D.Luc cells (BDS, Amsterdam, The Netherlands) were seeded in 96-well microtiter plates (Nunc, Rochester, NY, USA) at a density of 10,000 cells per well and were maintained in $0.1 \mathrm{ml}$ D-MEM/F-12 phenol red free medium, which was supplemented with $\mathrm{NaHCO}_{3}\left(1.26 \mathrm{~g} \mathrm{~L}^{-1}\right), 1 \%(\mathrm{v} / \mathrm{v})$ nonessential amino acids, and $5 \%(\mathrm{v} / \mathrm{v})$ dextran-coated charcoal-stripped fetal bovine serum (FBS, Australian origin). After $24 \mathrm{~h}$ of incubation $\left(37{ }^{\circ} \mathrm{C}, 5 \% \mathrm{CO}_{2}, 100 \%\right.$ relative humidity), the medium was renewed and cells were incubated for another 24 h. Sample extracts, solvent controls, a plate internal reference compound (EE2), and a serial dilution of E2, all in DMSO, were diluted 1000-fold in D-MEM/F-12 (containing $\mathrm{NaHCO}_{3}$, amino acids, stripped FBS). This yielded exposure media with a final DMSO concentration of $0.1 \%(\mathrm{v} / \mathrm{v})$. After removing the medium from the microtiter plates, T47D.Luc cells were exposed in triplicate to $0.1 \mathrm{ml}$ of exposure medium. ER-mediated activity was quantified after an exposure time of $24 \mathrm{~h}$. Triplicate analysis of each sample was repeated in a total of 3-4 independent exposure experiments. To assess the influence of dose and time on ER-mediated activity, cells were exposed for 12, 24, 48, and $72 \mathrm{~h}$ with a dilution series of samples Ref and $\mathrm{xClCuF}$ (Table 1). After the exposure of cells, the medium was removed and $0.05 \mathrm{ml}$ lysis reagent (Promega, Madison, WI, USA) was added. Luciferase activity was measured as relative light units (RLUs) on a microplate luminometer (MLX, Dynex, Chantilly, VA, USA) using luciferase assay reagent [31]. All RLU values were corrected for background activity detected in the presence of DMSO alone. Data obtained from the E2 dilution series were fitted to a sigmoid curve $\left(y=a_{0} /\left[1+\left(x / a_{1}\right)^{a 2}\right] ; y\right.$, measured activity in RLUs; $x$, E2 concentration in well; $a_{0}$, maximum activity in RLUs; $a_{1}, \mathrm{EC}_{50} ; a_{2}$, slope parameter; user-defined curve fit in Microsoft Excel 2003). Luciferase activities induced by extracts of diesel exhaust were converted to E2-CEQ concentrations using the inverse function of the fitted E2 curve $\left(x=a_{1}\left(\left[a_{0} / y-1\right]^{1 / a 2}\right)\right)$. Details on the cell culture and quality assurance/quality control for assay analysis are given in the "Electronic supplementary material." An ER antagonist, ICI 182,780 (Tocris Bioscience, Avonmouth, UK) [15], was mixed with E2 (3 pM, $10 \mathrm{pM})$ and with two samples (Ref, $\mathrm{xClCuF}$ ), yielding a final concentration of $10 \mathrm{nM} \mathrm{ICI}$ 182,780 [12] and $0.2 \%$ DMSO. This was done to test whether the detected luciferase activity was ER-mediated or not.

Mixture effect of $17 \beta$-estradiol (E2) and diesel exhaust

Extracts of diesel exhaust were tested in combination with a low concentration of E2 (3 pM) [12] to assess whether luciferase activities induced by E2 and diesel exhaust are 
additive or compounds present in diesel exhaust suppress the activity of E2. Stably transfected cells (T47D.Luc) were exposed for $24 \mathrm{~h}$ to mixtures of E2 and exhaust samples at a final DMSO concentration of $0.2 \%$. On the same plate, E2 $(3 \mathrm{pM})$ and samples were analyzed individually $(0.2 \%$ DMSO). The same sample dilutions were used to quantify the overall ER-mediated activity after $24 \mathrm{~h}$ of exposure. Luciferase activities, induced by E2 alone ( $3 \mathrm{pM})$ and samples alone, were converted into $\mathrm{pM}$ E2-CEQs using the fitted dose-response curve of E2. The arithmetic sum of the E2CEQ concentration of E2 and of a sample yielded the expected estrogenic activity of the mixture, assuming that the activities were additive. The actually measured estrogenic activity of the mixtures was expressed as a percentage of the expected E2-CEQ concentration.

\section{Statistics}

Single-factor ANOVA with post hoc testing (Tukey) was performed for multisample comparisons (Systat 10). $P$-values are mentioned in the "Results and discussion" section.

\section{Results and discussion}

Suitability of the ER-CALUX assay to investigate diesel exhaust

The ER-CALUX ${ }^{\circledR}$ assay was used to detect and quantify constituents of diesel exhaust that trigger $17 \beta$-estradiol (E2)-like gene expression. To test whether measured luciferase activities were estrogen receptor (ER)-mediated or induced by other pathways, we added an antagonist for the ER $(10 \mathrm{nM}$ ICI 182,780) to two solutions of E2 (3 pM and $10 \mathrm{pM}$ ), to a sample of unfiltered exhaust (Ref, Table 1), and to a sample of filtered exhaust (xClCuF, Table 1). As shown in Fig. 1, luciferase was expressed in the presence of E2 as well as in the presence of the exhaust samples. After the addition of the antagonist (ICI 182,780), luciferase induction by E2 and by both samples was completely inhibited. Cells were examined under the light microscope at the beginning and at the end of an exposure experiment. No morphological changes were evident that pointed to cytotoxic effects induced by the tested mixtures. Thus, E2 and both diesel exhaust samples exhibited ERmediated activity in the ER-CALUX ${ }^{\circledR}$ assay.

Figure 2 shows the dose-response curve of E2, the reference compound used. Unfiltered (Ref) as well as DPFtreated exhaust $(\mathrm{xClCuF})$ induced a dose-dependent response, which was similar to the lower part of the E2 curve (Fig. 2). For both exhaust samples, a full dose-response curve could not be achieved due to the high viscosity and/ or precipitation that occurred in highly undiluted samples.

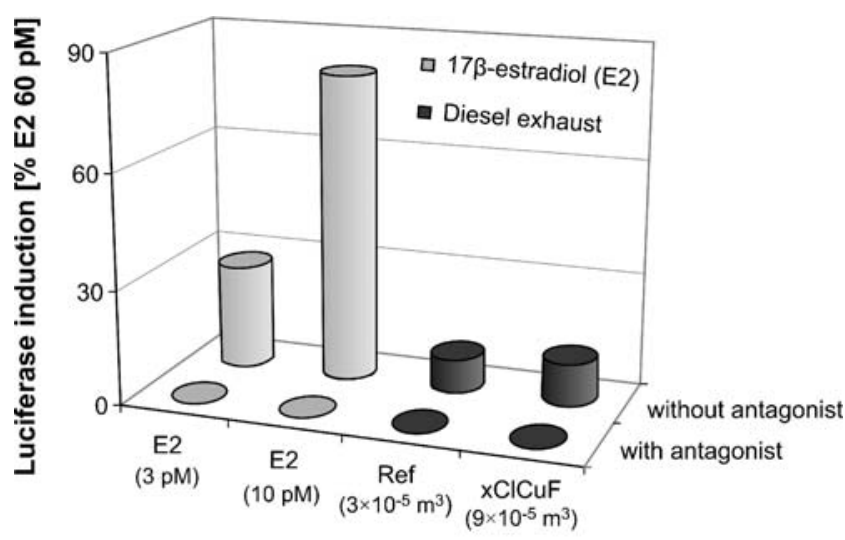

Sample code

Fig. 1 Estrogen receptor (ER)-mediated luciferase induction (ER$\mathrm{CALUX}^{\circledR}, 24 \mathrm{~h}$ of exposure) of $17 \beta$-estradiol (E2; 3 pM, $10 \mathrm{pM}$; gray columns) and samples of unfiltered and filtered diesel exhaust (Ref, $\mathrm{xClCuF}$; black columns). The diesel exhaust samples represent different sample volumes. No induction was detected (i.e., <LOD) after the addition of an antagonist for the ER (10 nM ICI 182,780; with antagonist). Data are expressed as luciferase induction in percent of the highest calibration point used (60 pM E2). Columns show the means of triplicate determinations in one exposure experiment (relative standard deviation $<10 \%$ )

Nevertheless, quantitative analysis was possible, because the dose-dependent activity of the exhaust samples was found to lie between the limit of quantification (LOQ) and the $25 \%$ effect concentration $\left(\mathrm{EC}_{25}\right)$ of $\mathrm{E} 2$. For the definition of the LOQ, please see the "Electronic supplementary material." To calculate E2 CALUX equivalent (E2-CEQ) concentrations, we selected sample dilutions that induced luciferase activity near to the $\mathrm{LOQ}$, but not above $20 \%$ of the maximal induction level of $\mathrm{E} 2$ (i.e., activity at $\mathrm{EC}_{20}$ ). It has been found that CALUX analyses performed on the lower part of the curve of the reference compound result in more precise and less variable data, and thus give more reliable results [32].

The ER-CALUX ${ }^{\circledR}$ assay is based on living cells that may be affected by numerous factors which may vary over time; for example, variations in cultivation conditions or variations in cell numbers per well of a plate. For each sample, determination of the E2-CEQ concentration was repeated by the same operator on 3-4 different days. The relative standard deviation (RSD) of these interplate determinations was $3-19 \%$. This is well below $30 \%$ RSD, a quality criterion commonly accepted for bioassay analyses of food and feedstuffs [32].

Estrogen receptor (ER)-mediated activity of unfiltered diesel exhaust

After an exposure time of $24 \mathrm{~h}$, all tested extracts exhibited ER-mediated activity, which was expressed as E2-CEQ concentrations (Fig. 3). For diesel exhaust generated with 
E2 concentration [pM]

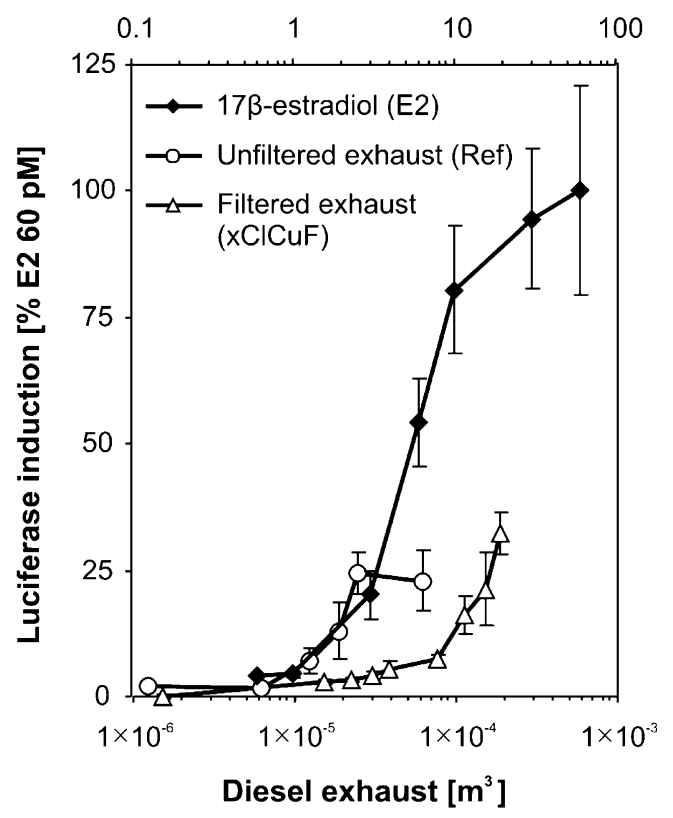

Fig. 2 Dose-response curves of $17 \beta$-estradiol (0.6-60 pM E2; rhombs), a sample of unfiltered diesel exhaust (Ref; circles), and a sample of diesel exhaust treated by a diesel particulate filter $(\mathrm{xClCuF}$; triangles) (ER-CALUX ${ }^{\circledR}, 24-\mathrm{h}$ data). Data are expressed as luciferase induction in percent of the $60 \mathrm{pM}$ E2 calibration point. Each data point represents the mean \pm standard deviation of a triplicate determination in one exposure experiment

reference fuel (sample Ref), we determined a concentration of $1.63 \pm 0.31 \mathrm{ng}$ E2-CEQ $\mathrm{m}^{-3}$ of exhaust. ER-mediated activities per $\mathrm{kWh}$ and per $\mathrm{L}$ of consumed diesel fuel are mentioned in the "Electronic supplementary material" (Table S1). So far, substituted phenols and their derivatives as well as PAHs and their derivatives have been identified as compounds with known or suspected ER-mediated activities present in diesel exhaust $[8,9,19]$. In comparison to the reference point (Ref), the E2-CEQ concentrations were lowered when the reference fuel was blended with the iron- or copper/iron-based catalyst (Fig. 3). We measured $1.31 \pm 0.13 \mathrm{ng}^{2} 2-\mathrm{CEQ} \mathrm{m}{ }^{-3}$ in sample Fe and $1.05 \pm 0.07 \mathrm{ng}$ E2-CEQ $\mathrm{m}^{-3}$ in sample $\mathrm{Cu}$. The observed decrease was significant for the copper/iron-based sample $(p=0.001)$, but not for the iron-based sample $(p=0.146)$. We conclude that, even in the absence of a DPF, the copper/iron-based catalyst reduced the estrogenic activity of the exhaust by $36 \%$. As shown in Fig. 3, the presence of some chlorine $\left(14 \mu \mathrm{g} \mathrm{Cl} \mathrm{g}^{-1}\right)$ did not affect the ER-mediated activity of the emitted exhaust. We found $1.62 \pm 0.24 \mathrm{ng}^{\mathrm{E} 2-\mathrm{CEQ} \mathrm{m}^{-3}}$ in the chlorine-based sample $(\mathrm{Cl})$. Likewise, the combined use of chlorine $\left(14 \mu \mathrm{g} \mathrm{Cl} \mathrm{g}^{-1}\right)$ and the iron-based catalyst did not exhibit a significant effect on ER-mediated activity $(p=0.720)$. We measured $1.83 \pm 0.17 \mathrm{ng}$ E2-CEQ $\mathrm{m}^{-3}(\mathrm{ClFe})$. The effect of chlorine in combination with the copper/ironbased catalyst was not evaluated.
As mentioned, blending of reference diesel fuel with the copper/iron-based catalyst resulted in a decrease of the E2CEQ concentration by $36 \%$. We suppose that the copper/ iron-based catalyst converted some of the ER agonists to nonactivating compounds, for example by oxidation of functional groups crucial for receptor binding. However, the use of metal-based fuel additives, which unavoidably leads to the formation of secondary nanoparticles [29], is allowed only in combination with efficient filter technology. For the DPFs tested in this study, the blending of fuel with catalysts is necessary to properly combust soot trapped in DPFs. Besides the use of catalytic fuel additives, catalyst-coated DPFs have also been successfully introduced [27].

Effects of diesel particulate filters on ER-mediated activity

DPFs are increasingly used for on- and off-road applications due to more stringent regulations for particulate matter emissions; for example, in several European countries, in Japan, and in the United States $[1,3]$. Therefore, we were interested in the effects of DPFs on the ER-mediated activity of the exhaust. In addition to samples of unfiltered exhaust, samples of filtered exhaust were analyzed using the ER-CALUX ${ }^{\circledR}$ assay. Effects of the two additive-catalyzed DPF systems on the emissions of estrogenic and antiestrogenic compounds were studied using chlorine-free and chlorine-enriched diesel fuels (Table 1).

Figure 3 illustrates that both DPFs clearly lowered E2CEQ concentrations. Compared to the reference point (Ref), the emitted E2-CEQ concentration was reduced by $55 \%$ in case of the iron-catalyzed DPF $(p<0.001)$ and by $66 \%$ in case of the copper/iron-catalyzed DPF $(p<0.001)$. Mean E2-CEQ concentrations of $0.74 \pm 0.07(\mathrm{FeF})$ and $0.55 \pm 0.09$ $(\mathrm{CuF}) \mathrm{ng}$ E2-CEQ $\mathrm{m}^{-3}$ were found. These findings demonstrate a beneficial secondary effect of the two tested DPFs in respect to emissions of ER ligands. The observed decrease reflects effects of physical filtration and effects of the catalysts on compounds showing ER-mediated activity. Consequently, the application of catalytic DPFs is expected to reduce the ER-mediated endocrine-disrupting potential of the exhaust. Furthermore, our results indicate that particles trapped in DPFs must act as carriers for a substantial fraction of the ER ligands present in diesel exhaust. The approach used does not provide information on individual estrogenic and antiestrogenic compounds. However, further efforts are needed to investigate differences in the compositions of the active fractions of filtered and unfiltered exhaust; for example, through the combined use of the ER-CALUX ${ }^{\circledR}$ assay and chemical analysis.

According to our considerations in the "Introduction," we supposed that a decrease in estrogenic activity would be observed if an appreciable amount of estrogenic compounds is sorbed to trapped particles. Consequently, those estrogenic 


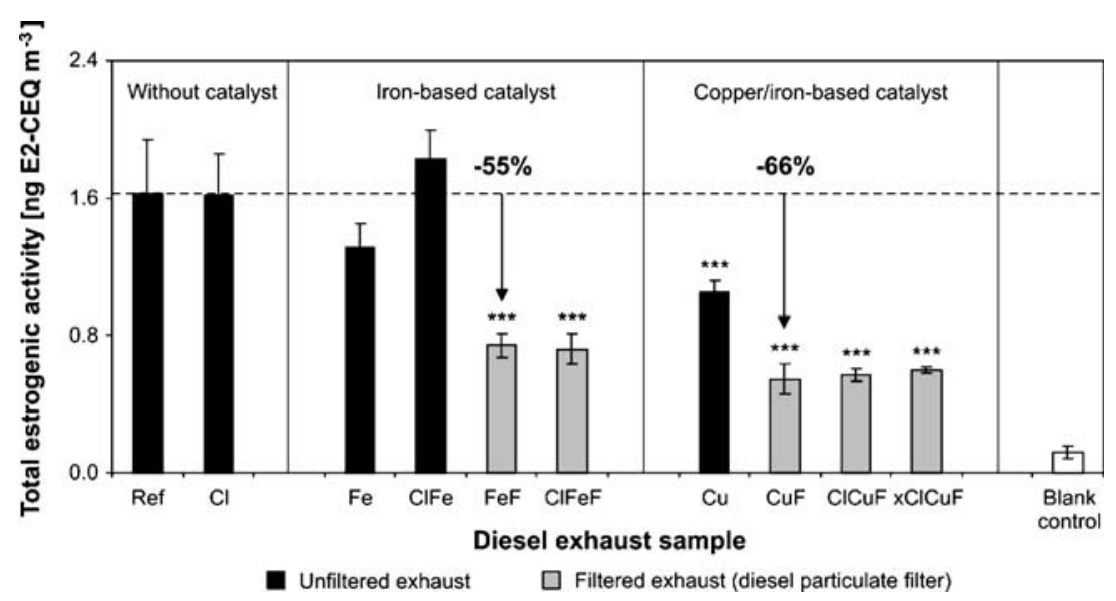

Fig. 3 Overall estrogenic activity (ER-CALUX ${ }^{\circledR}, 24-\mathrm{h}$ data) of unfiltered (black bars) and filtered (gray bars) exhaust. Activity is expressed as $17 \beta$-estradiol CALUX equivalents per $\mathrm{m}^{3}$ of diesel exhaust (E2-CEQ $\mathrm{m}^{-3}$ ). Experimental conditions: Ref, reference fuel; $\mathrm{Fe}$, fuel with iron-based catalyst $\left(4.5 \mu \mathrm{g} \mathrm{Fe}^{-1}\right) ; \mathrm{Cu}$, fuel with copper/

compounds still released from the DPF would either not be sorbed to trapped particles or would be emitted at higher operating temperatures or formed in the DPFs (e.g., by selective hydroxylation of primary exhaust constituents). Interestingly, the efficiency of both DPFs at reducing the ERmediated activity of the exhaust was lower than their efficiency at reducing the AhR-mediated activity. Both DPFs reduced emissions of AhR agonists by almost 90\% [7].

The addition of chlorine to the reference fuel (i.e., 14 or $110 \mu \mathrm{g} \mathrm{Cl} \mathrm{g}^{-1}$ ) did not influence the efficiencies of both DPFs at lowering the estrogenic activity of the exhaust. E2-CEQ concentrations in samples $\mathrm{FeF}$ and $\mathrm{ClFeF}$ and accordingly in samples $\mathrm{CuF}, \mathrm{ClCuF}$, and $\mathrm{xClCuF}$ did not differ from each other (Fig. 3). In a preceding in vitro study [7], we observed that AhR-mediated activity of the exhaust was moderately increased compared to all other DPF-treated samples when the copper/iron-catalyzed DPF was used in combination with diesel fuel with a high chlorine content (sample $\mathrm{xClCuF}$, Table 1). This was due to an intense secondary formation of PCDD/Fs, as previously detected by chemical analysis [3]. PCDD/Fs activate the AhR and have been shown to induce antiestrogenic effects [16]. Although a moderate increase of the overall AhRmediated activity was found for sample $\mathrm{xClCuF} \mathrm{[7],} \mathrm{we} \mathrm{did}$ not observe a suppressing effect on the total ER-mediated activity in comparison to other samples of filtered exhaust (Fig. 3).

Mixture effect of $17 \beta$-estradiol (E2) and diesel exhaust

As discussed, exhaust treatment by DPFs lowered the estrogenic activity of the exhaust. We hypothesized that this resulted either from physical filtering of ER ligands com- iron-based catalyst $\left(9.0 \mu \mathrm{g} \mathrm{Cu} \mathrm{g}^{-1} ; 7.5 \mu \mathrm{g} \mathrm{Fe} \mathrm{g}^{-1}\right) ; \mathrm{Cl}$, chlorineenriched fuel $\left(14 \mu \mathrm{g} \mathrm{Cl} \mathrm{g}^{-1}\right) ; x \mathrm{Cl}$, chlorine-enriched fuel $\left(110 \mu \mathrm{g} \mathrm{Cl} \mathrm{g}^{-1}\right)$; $F$, exhaust treatment by diesel particulate filter. Each bar represents the mean \pm standard deviation of 3-4 independent exposure experiments. $(* * *, p \leq 0.001$, compared with Ref)

bined with effects of the catalysts or from a secondary formation of compounds that suppress estrogenic activity. To verify if antiestrogenic compounds are relevant in this context, exhaust samples were mixed with E2 and the mixtures were tested using the ER-CALUX ${ }^{\circledR}$ assay.

Figure 4 shows that all mixtures exhibited ER-mediated activity below the expected additive activity, which was defined as the sum of the individually tested activities of E2 and of diesel exhaust. ER-mediated activity of the mixtures was even below the activity of E2 alone for samples ClFe, $\mathrm{Cu}$, and $\mathrm{CuF}$. Cytotoxic effects exhibited by the mixtures were not observed. These findings point to the presence of exhaust constituents that are able to suppress the activity of E2. Antiestrogenic activity has also been observed in earlier in vitro studies, for example by Okamura and coworkers. [18]. Another study showed that monohydroxy derivatives of PAHs present in diesel exhaust show estrogenic as well as antiestrogenic activities (reviewed by [22]).

As illustrated by Fig. 4, there was no difference in the additivity between mixtures containing samples of unfiltered exhaust and mixtures containing samples of filtered exhaust. Thus, we suggest that exhaust treatment by DPF lowers the estrogenic activity of the exhaust by reducing emissions of ER ligands, but not via the secondary formation of antiestrogenic compounds.

ER-mediated activity of diesel exhaust over varying exposure times

We used an exposure time of $24 \mathrm{~h}$ to determine the E2-CEQ concentrations of the ten samples collected (Table 1). To test if ER-mediated activity of diesel exhaust changes over time, we exposed T47D.Luc cells to a sample of unfiltered exhaust (Ref) and to a sample of DPF-treated exhaust 


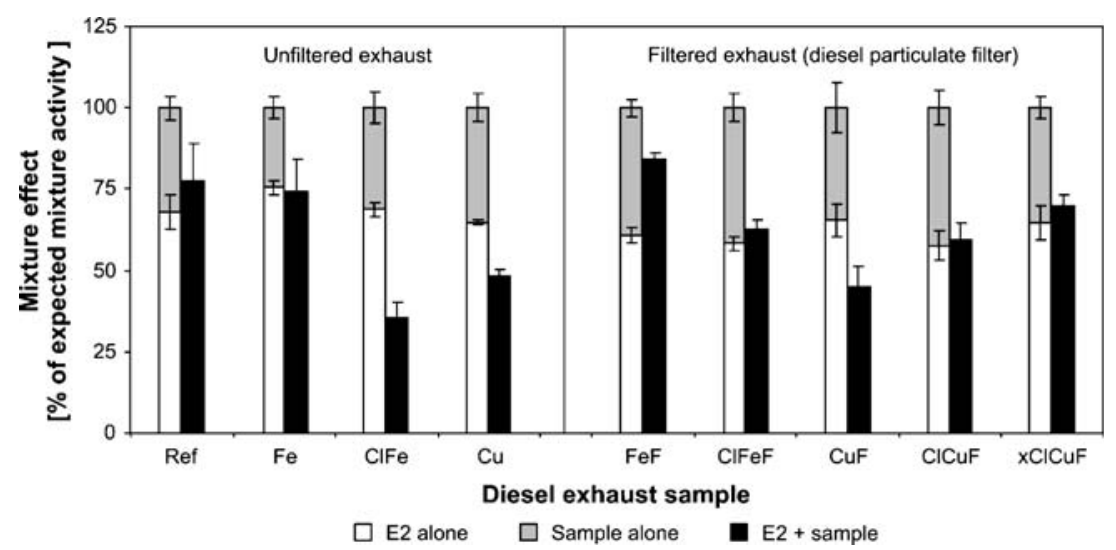

Fig. 4 Expected and measured mixture effects of $3 \mathrm{pM} 17 \beta$-estradiol and unfiltered or filtered diesel exhaust. Estrogenic activities of $17 \beta-$ estradiol (E2 alone; white bars) and of diesel exhaust (sample alone; gray bars) were measured individually, converted into pM E2

$(\mathrm{xClCuF})$ at various exposure times of $12,24,48$, and $72 \mathrm{~h}$. Longer exposure experiments were not conducted because ideal conditions for cell culture could not be maintained (e.g., due to acidification of the medium).

Figure 5 illustrates that ER-mediated activity was nearly constant from 12 to $72 \mathrm{~h}$ of exposure. Exhaust treatment by DPF did lower the ER ligand level compared to the reference sample (Ref), but did not affect the ER-mediated activity during the tested exposure times. Figure 5 indicates that ER ligands were not biotransformed into nonactivating compounds by T47D cells within $72 \mathrm{~h}$. This may be because either the exposed cells do not possess the required metabolic pathways or because ER ligands in diesel exhaust are not degradable. So far, the metabolic capacity of in vitro bioassays for estrogenicity is not well understood [33]. It has been reported that T47D breast cancer cells express the cytochrome P450 enzymes [12, 16], which are involved in the hydroxylation of estrogens and xenobiotics. Thus, T47D.Luc cells may possess some but probably not much metabolic capability. In contrast to ER-mediated activity, AhR-mediated activity of unfiltered as well as filtered exhaust decreased by more than $90 \%$ over a time period of $72 \mathrm{~h}$ [7], as previously detected using an in vitro reporter gene assay based on rat hepatoma cells (DR-CALUX ${ }^{\circledR}$ ). This decrease was expected, because liver cells are characterized by their ability to metabolize exogenous and endogenous compounds, the $\mathrm{AhR}$ is involved in the initialization of biotransformation pathways, and certain AhR agonists are known to be metabolized within a short time [34].

\section{Conclusions}

Our findings confirm that diesel exhaust contains compounds that are able to induce ER-mediated gene expression, as well as compounds that are able to suppress E2-induced
CALUX equivalents (E2-CEQs), and summed, yielding the expected activities of the mixtures. The actually measured E2-CEQs induced by the mixtures (black bars) were expressed as percentages of the expected activity. (Sample $\mathrm{Cl}$ was not measured)

activity [8, 17-19]. Estrogenic activity prevailed over antiestrogenic activity in the extracts analyzed. In unfiltered diesel exhaust (Ref), we measured an overall concentration of ER agonists of $1.6 \pm 0.3 \mathrm{ng}$ E2-CEQ $\mathrm{m}^{-3}$. This exceeded E2-CEQ concentrations found in urban air particulate matter $[35,36]$ by a factor of 5-70. Hence, diesel engines operated without DPFs seem to be an important source of atmospheric ER ligands. These potential endocrine disruptors may modulate the activity of endogenous estrogens in humans and animals and so may lead to adverse health effects [11].

Diesel engine emissions are ubiquitous in the environment. In addition to the frequent use of diesel-powered

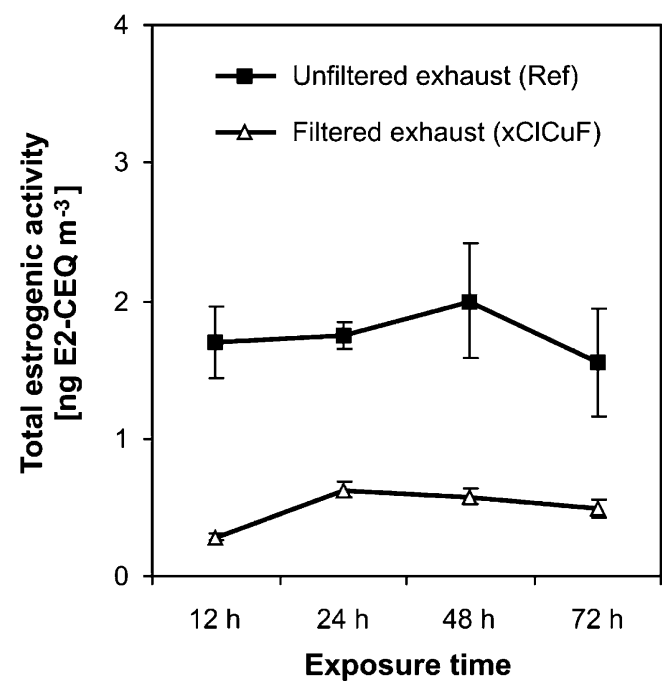

Fig. 5 Overall estrogenic activity of a sample of unfiltered diesel exhaust (Ref; squares) and a sample of exhaust treated by a diesel particulate filter (xClCuF; triangles), determined using the ERCALUX $^{\circledR}$ assay with varying exposure times $(12-72 \mathrm{~h})$. Estrogenic activities were expressed as E2 CALUX equivalents per $\mathrm{m}^{3}$ of diesel exhaust (E2-CEQ $\mathrm{m}^{-3}$ ). Each data point represents the mean of a triplicate determination in one exposure experiment (relative standard deviation $\leq 25 \%$ ) 
equipment in various workplaces, the use of diesel-fueled passenger cars is expected to increase. The market share of diesel cars is approaching $40 \%$ of new vehicle registrations today, and will most likely reach the 50\% mark in Europe in the near future [27]. Our study shows that the DPFs tested lowered the E2-CEQ concentrations by 55 and $66 \%$, and thus lowered the emissions of ER ligands with potential endocrine-disrupting properties. Hence, DPF applications may be of particular importance for persons that work or live at places exposed to diesel exhaust $[25,26]$. Such places are, for example, underground workplaces where dieselpowered equipment is used (e.g., mines, tunnels) and heavy traffic areas with impaired exchange of air (e.g., urban canyons, tollgate cabins). We observed a better efficiency of the copper/iron-catalyzed DPF at reducing the ER-mediated activity of the exhaust. However, investigation of the PCDD/ $\mathrm{F}$ formation potential showed that copper-catalyzed DPFs should not be recommended for use, because substantial amounts of PCDD/Fs were formed in this DPF under certain conditions [3]. Hence, to approve DPF systems for use, secondary effects of DPFs should not be assessed solely based on the analysis of a single group of harmful compounds.

The ER-CALUX ${ }^{\circledR}$ assay has proven to be a valuable tool for studying estrogenic and antiestrogenic constituents of diesel exhaust and examining secondary effects of DPFs on emissions of potential endocrine disruptors. In the future, bioassays may be a useful approach for assessing the efficiency of DPF systems or testing other exhaust treatment technologies on a larger scale.

Acknowledgements We thank all our collaborators at Empa, BFHTI Biel, and TTM Niederrohrdorf for providing exhaust samples and know-how. This study was supported by the board of Empa and the Swiss National Science Foundation (NRP50 program, grant no. 40504-104378).

\section{References}

1. van Setten BAAL, Makkee M, Moulijn JA (2001) Catal Rev 43:489-564

2. Zhu Y, Hinds WC, Kim S, Shen S, Sioutas C (2002) Atmos Environ 36:4323-4335

3. Heeb NV, Zennegg M, Gujer E, Honegger P, Zeyer K, Gfeller U, Wichser A, Kohler M, Schmid P, Emmenegger L, Ulrich A, Wenger D, Petermann J-L, Czerwinski J, Mosimann T, Kaspar M, Mayer A (2007) Environ Sci Technol 41:5789-5794

4. Riedl M, Diaz-Sanchez D (2005) J Allergy Clin Immunol 115:221-228

5. Delfino RJ, Sioutas C, Malik S (2005) Environ Health Perspect 113:934-946

6. Brüske-Hohlfeld I, Möhner M, Ahrens W, Pohlabeln H, Heinrich J, Kreuzer M, Jöckel K-H, Wichmann H-E (1999) Am J Indust Med 36:405-414
7. Wenger D, Gerecke AC, Heeb NV, Zennegg M, Kohler M, Naegeli H, Zenobi R (2008) Environ Sci Technol (in press, DOI $10.1021 / \mathrm{es} 071827 \mathrm{x}$ )

8. Furuta C, Suzuki AK, Taneda S, Kamata K, Hayashi H, Mori Y, Li CM, Watanabe G, Taya K (2004) Biol Reprod 70:1527-1533

9. Sidhu S, Gullett B, Striebich R, Klosterman J, Contreras J, DeVito M (2005) Atmos Environ 39:801-811

10. Colborn T, vom Saal FS, Soto AM (1993) Environ Health Perspect 101:378-384

11. World Health Organization (WHO), International Labour Organisation (ILO), United Nations Environment Programme (UNEP) (2002) Global assessment of the state-of-the-science of endocrine disruptors. In: T. Damstra, Sue Barlow, Aake Bergman, Robert Kavlock, Glen van der Kraak (eds). International Programme on Chemical Safety (ICPS)

12. Legler J, van den Brink CE, Brouwer A, Murk AJ, Van der Saag PT, Vethaak DA, Van der Burg B (1999) Toxicol Sci 48:55-66

13. Nilsson S, Mäkelä S, Treuter E, Tujague $M$, Thomsen J, Andersson G, Enmark E, Pettersson K, Warner M, Gustafsson J-A (2001) Physiol Rev 81:1535-1565

14. Villeneuve DL, Blankenship AL, Giesy JP (1998) Interactions between environmental xenobiotics and estrogen receptor-mediated responses. In: Denison, MS, Helferich, WG (eds) Toxicant-receptor interactions. Taylor \& Francis, Philadelphia, PA

15. Howell A, Osborne KC, Morris C, Wakeling AE (2000) Am Cancer Soc 817-825

16. Safe S, Wormke M (2003) Chem Res Toxicol 16:807-816

17. Meek MD (1998) Environ Res 79:114-121

18. Okamura K, Kizu R, Toriba A, Klinge CM, Hayakawa K (2002) Polycycl Aromat Comp 22:747-759

19. Wang J, Wu W, Henkelmann B, You L, Kettrup A, Schramm KW (2003) Atmos Environ 37:3225-3235

20. Watanabe N, Kurita M (2001) Environ Health Perspect 109:111-119

21. Watanabe N (2005) Toxicol Lett 155:51-58

22. Takeda K, Naomi T, Yoshida S (2004) Environ Sci 11:033-045

23. Yoshida S, Takeda K (2004) J Health Sci 50:210-214

24. Ono N, Oshio S, Niwata Y, Yoshida S, Tsukue N, Sugawara I, Takano H, Takeda K (2007) Inhal Tox 19:275-281

25. Guo J, Kauppinen T, Kyyronen P, Heikkila P, Lindbohm ML, Pukkala F (2004) Int J Cancer 111:286-292

26. De Rosa M, Zarrilli S, Paesano L, Carbone U, Boggia B, Petretta M, Maisto A, Cimmino F, Puca G, Colao A, Lombardi G (2003) Hum Reprod 18:1055-1061

27. Schaefer-Sindlinger A, Lappas I, Vogt CD, Ito T, Kurachi $H$, Makino M, Takahashi A (2007) Top Catal 42-43:307-317

28. Schwarzenbach RP, Gschwend PM, Imboden DM (2003) Environmental organic chemistry. Wiley, Hoboken, NJ

29. Ulrich A, Wichser A (2003) Anal Bioanal Chem 377:71-81

30. CEN (1996) European Standard EN 1948-1. European Committee for Standardization (CEN), Brussels

31. Wenger D, Gerecke AC, Heeb NV, Zenobi R (2006) Organohal Comp 68:1295-1298

32. Van Wouwe N, Windal I, Vanderperren H, Eppe G, Xhrouet C, Massart A-C, Debacker N, Sasse A, Baeyens W, De Pauw E, Sartor F, Van Oyen H, Goeyens L (2004) Talanta 63:1157-1167

33. Martin OV, Lai KM, Scrimshaw MD, Lester JN (2005) Environ Sci Technol 39:5349-5355

34. Schmidt JV, Bradfield CA (1996) Annu Rev Cell Dev Biol 12:55-89

35. Clemons JH, Allan LM, Marvin CH, Wu Z, McCarry BE, Bryant DW, Zacharewski TR (1998) Environ Sci Technol 32:1853-1860

36. Wang J, Xie P, Xu Y, Kettrup A, Schramm K-W (2004) Atmos Environ 38:6157-6166 